medRxiv preprint doi: https://doi.org/10.1101/2021.08.06.21261689; this version posted August 9, 2021. The copyright holder for this preprint (which was not certified by peer review) is the author/funder, who has granted medRxiv a license to display the preprint in

No reuse allowed without permission.

1

Original Article

3

4

5 Authors: Tanvir Abir ${ }^{1}$, Uchechukwu Levi Osuagwu², Dewan Muhammad Nur-A Yazdani

$7 \quad$ Khanam $^{8}$, Kingsley Emwinyore Agho 9

\section{Internet Use impact on Physical Health during COVID-19 pandemic in Bangladesh: A Web-based Cross-sectional study}

\title{
Affiliation:
}

1. Associate Professor, College of Business Administration-CBA, International University of Business, Agriculture and Technology-IUBAT University, Dhaka 1230, Bangladesh; tanvir.cba@iubat.edu;

2. Diabetes, Obesity and Metabolism Translational Research Unit, Western Sydney University, Campbelltown, NSW 2560, Australia; African Vision Research Institute (AVRI), University of KwaZulu-Natal, Westville Campus, Durban, 3629, South Africa; l.osuagwu@westernsydney.edu.au;

${ }^{3}$. Assistant Professor, College of Business Administration-CBA, International University of Business, Agriculture and Technology-IUBAT University, Dhaka 1230, Bangladesh; dewanm@iubat.edu

${ }^{4}$. Faculty of Business and Management, UCSI University, Kuala Lumpur 56000, Malaysia; abdullaham@ucsiuniversity.edu.my;

5. Assistant Professor, Department of Philosophy, College of Arts and Sciences-CAAS, International University of Business, Agriculture and Technology-IUBAT University, Dhaka 1230, Bangladesh; kanizkakon@iubat.edu

${ }^{6}$. Department of Management Information Systems, College of Business Administration, Prince Sattam Bin Aziz University, 165 Al-Kharj 11942, Saudi Arabia. Email: a.salameh@psua.edu.sa

7. Lecturer, Faculty of Entrepreneurship and Business, Universiti Malaysia Kelantan, 16100 Kota Bharu, Malaysia; raihani@umk.edu.my

${ }^{8}$. Maternal and Child Nutrition, Nutrition and Clinical Services Division, icddr,b

Bangladesh; mansura@icddrb.org

9. Associate Professor, School of Health Science, Western Sydney University, Campbelltown, NSW 2560, Australia; African Vision Research Institute (AVRI), University of KwaZuluNatal, Westville Campus, Durban, 3629, South Africa; K.Agho@westernsydney.edu.au 
medRxiv preprint doi: https://doi.org/10.1101/2021.08.06.21261689; this version posted August 9, 2021. The copyright holder for this preprint (which was not certified by peer review) is the author/funder, who has granted medRxiv a license to display the preprint in All rights reserved. No perpetuity.

40

Funding: This research did not receive any funding.

Declaration of Conflict of Interest: The authors declare that they have no known competing financial interests or personal relationships that could have appeared to influence the work reported in this paper.

Author Contribution: Conceptualization, T.A. and D.M.N.-A. Y; Data curation, T.A. and K.A; Formal analysis, U.L.O. and K.A; Investigation, D.M.N.-A.Y. and M.K.; Methodology, T.A., A.A.M, A.A.S.; Project administration, K.A., D.M.N.-A.Y., K.K.; Resources, D.M.N.A.Y., A.A.M. and N.R.Z; Supervision, N.R.Z. and K.A.; Validation, T.A. and K.A.; Visualization, M.K. and K.A.; Writing—original draft, T.A. and U.L.O.

All authors have read and agreed to the published version of the manuscript.

Article Type: Original Research.

Keywords: Internet use, Coronavirus, Survey, Headache, Back pain, Neck pain, Physical health

Running Head: Internet use and Physical health of Bangladeshi Adults

Ethics Statement: Permission for this study (IUBAT/AR/2021/001) was obtained from the Institutional Review Board of International University of Business, Agriculture and Technology (IUBAT), Dhaka, Bangladesh. The study adhered to the tenets of the Declaration of Helsinki as revised in Fortaleza. All the participants were informed about the specific objective of this study before proceeding to the questionnaire. Consent was obtained from all participants prior to completing the questionnaire through an online preamble. Participants were able to complete the survey only once and could terminate the survey at any time they desired. Anonymity and confidentiality of the data were ensured.

Data Reference: Our data are included in the manuscript and raw data can be released at reasonable request. 
medRxiv preprint doi: https://doi.org/10.1101/2021.08.06.21261689; this version posted August 9, 2021. The copyright holder for this preprint (which was not certified by peer review) is the author/funder, who has granted medRxiv a license to display the preprint in All rights reserved. No reuse allowed without permission.

68

69

70

71

72

73

74

75

76

\section{Abstract}

Background: Bangladesh ranked fifth largest internet user in Asia. Past studies on internet use have focused on its impact on mental health, with little known about its impact on the physical health of individuals during COVID-19 pandemic. Hence, this study examines the impact of Internet use frequency on physical health during the Covid-19 lockdown in Bangladesh.

Methods: A web-based cross-sectional study on 3242 individuals aged 18 and above was conducted from $2^{\text {nd }}$ August $-1^{\text {st }}$ October 1, 2020, during the lockdown in Bangladesh. The survey covers demographics, Internet use frequency and physical health questions. Multiple linear regression analyses were used to examine the impact of internet use frequency on physical health.

Results: The result indicated that $72.5 \%, 69.9 \%, 65.1 \%$ and $55.3 \%$ reported headache, back pain, numbness of the fingers and neck pain, respectively. The multivariable analyses showed increased physical health impact among regular (coefficient $\beta=0.52,95 \%$ confidence interval [CI]: $0.18-0.85, P=0.003)$, frequent $(\beta=1.21,95 \% \mathrm{CI}: 0.88-1.54, P<.001)$ and intense $(\beta$ $=2.24,95 \% \mathrm{CI}: 1.91-2.57, P<.001)$ internet users. Other factors associated with physical health scores were gender, income (in Taka), occupation, regions, and working status.

Conclusion: Frequent, intensive, and extensive use of the internet were strong predictors of increased physical health problems, and the study suggests the need for raising awareness of physical health problems triggered by high internet users among the high socioeconomic group in Bangladesh. 
medRxiv preprint doi: https://doi.org/10.1101/2021.08.06.21261689; this version posted August 9, 2021. The copyright holder for this preprint (which was not certified by peer review) is the author/funder, who has granted medRxiv a license to display the preprint in All rights reserved. No perpetuity.

91

92

93

94

95

\section{INTRODUCTION}

The coronavirus disease 2019 (COVID-19) pandemic and the associated public health interventions, including social distancing, home quarantine measures, and 'stay-at-home' orders, put in place by the various governments, led to a surge in internet usage during the pandemic ${ }^{[1]}$. The lockdown measures resulted in widespread and unprecedented social disruption ${ }^{[2]}$ as non-essential businesses were closed or some employees worked from home and unemployment increased ${ }^{[3]}$. There were massive changes in internet usage patterns and user behaviour with employees having to adjust to the new "normals" - with meetings going completely online, office work shifting to the home, leading to new emerging patterns of work. These changes have come across most organizations, businesses, societies, or governments and suddenly, leaving barely any time for organizations and people to plan for, prepare and implement new setups and arrangements. Society has had to adjust, try, experiment, and find ways that did not exist before the pandemic ${ }^{[1]}$, and these may have implications on the physical health of individuals.

People are now spending even more time with technology while consuming news media, watching television, using social media to connect with others, utilizing lifestyle apps to shop for groceries and other consumer goods, and engaging in home workouts ${ }^{[2]}$. In Bangladesh, this kept parts of the economy going ${ }^{[4]}$ as the country witnessed a boom in internet usage due to the fast-growing mobile internet and the government's push for digitalization. Engaging in social media platforms is now a routine activity for children and adults, enhancing communication, social connection, and even technical skills ${ }^{[5]}$. Platforms such as Facebook and Twitter offer multiple daily opportunities for connecting with friends, classmates, and people with shared interests. The number of people using such sites has also increased dramatically over the last five years, as shown in a recent poll ${ }^{[6]}$. A past study reported that about $22 \%$ of teenagers $\log$ on to their favorite social media site more than ten times a day, and more than half of adolescents log on to a social media site more than once a 
medRxiv preprint doi: https://doi.org/10.1101/2021.08.06.21261689; this version posted August 9, 2021. The copyright holder for this preprint (which was not certified by peer review) is the author/funder, who has granted medRxiv a license to display the preprint in All rights reserved. No rerpetuity.

117

118

day ${ }^{[6,7]}$. Seventy-five percent of teenagers now own cell phones, $25 \%$ use them for social media, $54 \%$ use them for texting, and $24 \%$ use them for instant messaging ${ }^{[7]}$.

According to the Bangladesh Telecommunication Regulatory Commission, there were 99,428 million (approx. $60.9 \%$ of the population) internet users in February $2020^{[8]}$. Though there is anecdotal early evidence that this may lead to increased productivity, it has also led to increased stress ${ }^{[9,10]}$ where employees must learn new technologies, be available for work at almost all times, stay with digital devices all the time, and cope with multi-tasking ${ }^{[1]}$. The use of video-conferencing and content delivery services such as Zoom and Akamai also increased ${ }^{[1]}$. Those working from home using this technology have found themselves under intense scrutiny and tension ${ }^{[11]}$.

That a large part of the peoples' social and emotional development is occurring while on the Internet and cell phones may affect the physical health of individuals considering the long hours spent on the internet during the mandatory stay at home orders which expose the population to lots of misinformation ${ }^{[12]}$ known to affect physical and mental health ${ }^{[13]}$. Since this high use of information systems may become the new normal, this study examined the impact of internet usage frequency during the COVID-19 pandemic on Bangladeshi residents' physical and mental health and determined the level of addiction to social media platforms used by the people.

\section{Ethical consideration}

Permission for this study (IUBAT/AR/2021/001) was obtained from the Institutional Review Board of International University of Business, Agriculture and Technology (IUBAT), Dhaka, Bangladesh. The study adhered to the tenets of the Declaration of Helsinki as revised in Fortaleza. All the participants were informed about the specific objective of this study before and consent was obtained from all participants before completing the questionnaire through an online preamble. To avoid repeated responses and in order to ensure the validity of data to 
medRxiv preprint doi: https://doi.org/10.1101/2021.08.06.21261689; this version posted August 9, 2021. The copyright holder for this preprint (which was not certified by peer review) is the author/funder, who has granted medRxiv a license to display the preprint in All rights reserved. No reuse allower.

some extent, participants were able to complete the survey only once as data was restricted to their IP addresses and device. Participants could terminate the survey at any time they desired. Anonymity and confidentiality of the data were ensured.

\section{METHODS}

\section{Study population and sampling}

By convenience sampling, 3242 questionnaires were collected from adults aged 18 and over living in eight divisions across Bangladesh during the pandemic. All questionnaires were web-based, participation was voluntary, and each participant was informed about the study's background through an online preamble. No reward or incentive was offered for participation. There may be more than one questionnaire filled by the same person that affects the statistical analysis results of questionnaire data. In order to ensure the validity of data to some extent, restricting the same IP address and device are applied to the system, which means the participant of the same IP address or device only can fill once.

\section{Data Collection}

Data were collected using self-administered web-based questionnaires distributed to various groups of people via the E-link using numerous mailing lists and social network sites including Facebook, WhatsApp and Twitter. Due to the mandatory lockdown, no paper questionnaires were distributed, making it difficult to reach the very remote regions.

\section{Dependent variable}

Ten items of physical complaints reported in Table 2 below were used to determine the impact of individual physical health on Internet use. The respondents used a close-end response ['Yes' or 'No'] to indicate whether they suffered from the following ten problems (Back and neck pain, numbness in fingers, headaches, inability to sleep, dry eyes or other vision problems, poor nutrition, poor personal hygiene, weight gain/loss and loss of appetite] during or after pro-longed Internet use. Binary scores for individual questions were summed 
medRxiv preprint doi: https://doi.org/10.1101/2021.08.06.21261689; this version posted August 9, 2021. The copyright holder for this preprint (which was not certified by peer review) is the author/funder, who has granted medRxiv a license to display the preprint in All rights reserved. No perpetuity.

to give a physical health score which ranged from 0-10, and the Kuder Richardson coefficient measuring internal consistency among the physical health scores ranged from 0.65 to 0.78 , indicating a satisfactory level of reliability.

\section{Main study factor}

The main study variable was the respondent's Internet usage, including the average daily amount of time spent on the internet and dependence on networks. The frequency of internet use was categorized as 'seldom' ( $<1$ hour per day), 'casual' ( $\geq 1$ and $<3$ hours per day), 'regular' ( $\geq 3$ and $<5$ hours per day), 'frequent' ( $\geq 5$ and $<7$ hours per day), 'intense' ( $\geq 7$ hours per day) ${ }^{[14]}$.

\section{Independent variables}

Independent variables used for the study analyses were based on previous studies ${ }^{[14-16]}$. Independent variables included demographic characteristics (i.e., gender, age [categorized as 18-27, 28-37, 38 years and over], marital status [single, married, divorced/widowed], mothers level of education [Higher education, Bachelor, Intermediate], place of residence, employment status [Employed, unemployed/student], occupation [healthcare and nonhealthcare worker], and income in Taka [lower, middle and high-income earners].

\section{Statistical Analysis}

All statistical analyses were performed in Stata version 14.1 (Stata Corp. 2015, College Station USA) mainly using descriptive statistics; t-test used compares the means of two independent groups, One-way analysis of variance (one-way ANOVA) used compares the means of more than two independent groups, correlation analyses, and regression analysis. All confounding variables with a $P<.20$ were retained in the univariate linear regression analysis and were used to build a multivariable model ${ }^{[17]}$. A manual elimination procedure 
medRxiv preprint doi: https://doi.org/10.1101/2021.08.06.21261689; this version posted August 9, 2021. The copyright holder for this preprint (which was not certified by peer review) is the author/funder, who has granted medRxiv a license to display the preprint in All rights reserved. No perpetuity.

193

194

195

196

197

198

199

200

201

202

203

204

205

206

207

208

209

210

211

212

213

214

215

216

was applied for multivariate linear regression analyses to remove non-significant variables $(P$ $>$.05). The main study factor variable (Internet usage frequency) was added to all significant confounding variables after elimination processes. The main study factor and independent variables associated with physical health scores $(P<.05)$ were reported. In the regression analysis, we checked for homogeneity of variance and multicollinearity, including Variance Inflation Factors (VIF) and the VIF < 4 was considered suitable ${ }^{[18]}$ :

\section{RESULTS}

\section{Demographic Characteristics According to the Frequency of Internet Use among adults}

\section{in Bangladesh}

Table 1 depicts the main demographic characteristics, including gender, education and age group on the five groups extracted. It is worth noting that the education in this paper refers to that of the mothers' maximum educational level. The majority of participants were males $(1260,61.1 \%)$, married $(2632,81.2 \%)$ and employed $(2864,88.3 \%)$ in non-healthcare sectors (2567, 79.2\%), and for many, their mothers had completed a bachelor degree or higher. About half of the respondents earned more than 70,000 Taka at the time of data collection (Table 1).

About two-thirds of the respondents that reported intense use of the internet were males, while females were more likely to report regular and casual use of the internet. More than half of intense and frequent internet users were aged 28-37years, and a similar proportion of casual internet users were younger (18-27years). Nearly all intense internet users were employed and working in the non-Health care sector during the study.

Table 1 Demographic Characteristics According to the Frequency of Internet Use among adults in Bangladesh. Values are expressed as numbers and percentages (n, \%).

\begin{tabular}{lllllll}
\hline Variables & $\begin{array}{l}\text { Total } \\
(\mathbf{N}=3236)\end{array}$ & $\begin{array}{l}\text { Intense } \\
(\mathbf{n}=1668)\end{array}$ & $\begin{array}{l}\text { Frequent } \\
(\mathbf{n}=689)\end{array}$ & $\begin{array}{l}\text { Regular } \\
(\mathbf{n}=559)\end{array}$ & $\begin{array}{l}\text { Casual } \\
(\mathbf{n}=187)\end{array}$ & $\begin{array}{l}\text { Seldom } \\
(\mathbf{n}=93)\end{array}$ \\
\hline Demography & & & & & & \\
\hline
\end{tabular}


medRxiv preprint doi: https://doi.org/10.1101/2021.08.06.21261689; this version posted August 9, 2021. The copyright holder for this preprint (which was not certified by peer review) is the author/funder, who has granted medRxiv a license to display the preprint in All rights reserved. No reuse allowed without permission.

\begin{tabular}{|c|c|c|c|c|c|c|}
\hline \multicolumn{7}{|l|}{ Gender } \\
\hline Male & $1976(61.1)$ & $1179(70.7)$ & $382(55.4)$ & $264(44.1)$ & $93(44.7)$ & $58(62.4)$ \\
\hline Female & $1260(38.9)$ & $489(29.3)$ & $307(44.6)$ & $335(55.9)$ & $94(50.3)$ & $35(37.6)$ \\
\hline \multicolumn{7}{|l|}{ Age in years } \\
\hline $18-27$ & $555(17.2)$ & $30(1.8)$ & $156(22.6)$ & $254(42.1)$ & $98(52.4)$ & 17 (17.9) \\
\hline $28-37$ & $1657(51.1)$ & $956(57.3)$ & $366(53.1)$ & $238(39.5)$ & $60(32.1)$ & $37(39.0)$ \\
\hline $38+$ & $1030(31.8)$ & $682(40.9)$ & $167(24.2)$ & $111(18.4)$ & $29(15.5)$ & $41(43.2)$ \\
\hline \multicolumn{7}{|l|}{ Marital status } \\
\hline Single & $508(15.7)$ & $29(1.7)$ & $150(21.8)$ & $223(37.0)$ & $90(48.1)$ & $16(16.8)$ \\
\hline Married & $2632(81.2)$ & $1632(97.8)$ & $505(73.3)$ & $339(56.2)$ & $83(44.40)$ & $73(76.8)$ \\
\hline Divorced/widow & $102(3.1)$ & $7(0.4)$ & $34(4.9)$ & $41(6.8)$ & $14(7.49)$ & $6(6.3)$ \\
\hline \multicolumn{7}{|l|}{ Place of residence (\%) } \\
\hline Barisal Division & $172(5.31)$ & $70(4.20)$ & $48(7.0)$ & $35(5.0)$ & $7(3.7)$ & $12(12.6)$ \\
\hline Chittagong Division & $291(9.0)$ & $100(6)$ & $107(15.5)$ & $61(10.1)$ & $16(8.6)$ & $7(7.4)$ \\
\hline Dhaka Division & $1574(48.6)$ & $1010(60.6)$ & $205(29.8)$ & $236(39.1)$ & $95(50.8)$ & $28(29.5)$ \\
\hline Khulna Division & $352(10.9)$ & $115(6.9)$ & $109(15.8)$ & $92(15.3)$ & $20(10.7)$ & $16(16.8)$ \\
\hline Mymensingh Division & $313(9.7)$ & $127(7.6)$ & $76(11.0)$ & $85(14.1)$ & $17(9.1)$ & $8(8.4)$ \\
\hline Rajshahi Division & $213(6.6)$ & $99(5.9)$ & $47(6.8)$ & $41(6.8)$ & $18(9.6)$ & $8(8.4)$ \\
\hline Rangpur Division & $179(5.5)$ & $93(5.6)$ & $45(6.5)$ & $22(3.7)$ & $9(4.8)$ & $10(10.5)$ \\
\hline Sylhet Division & $148(4.6)$ & $54(3.2)$ & $52(7.6)$ & $31(5.1)$ & $5(2.7)$ & $6(6.3)$ \\
\hline \multicolumn{7}{|l|}{ Mother's Level of } \\
\hline $\begin{array}{l}\text { Higher education } \\
\text { (above }\end{array}$ & $1287(39.7)$ & $684(41.0)$ & $341(49.5)$ & $178(29.5)$ & $46(24.6)$ & $38(40)$. \\
\hline Bachelor & $1514(46.7)$ & $961(57.6)$ & $226(32.8)$ & 233 (38.6) & $67(35.8)$ & $27(28.4)$ \\
\hline Intermediate (11-12) & $441(13.6)$ & $23(1.4)$ & $122(17.7)$ & $192(31.84)$ & $74(39.5)$ & $30(31.6)$ \\
\hline \multicolumn{7}{|l|}{ Working status } \\
\hline Employed & $2864(88.3)$ & $1647(98.7)$ & $600(87.1)$ & 432 (71.6) & $99(52.9)$ & $86(91.0)$ \\
\hline Not employed/student & 378 (11.7) & $21(1.3)$ & 89 (12.9) & $171(28.4)$ & $88(47.1)$ & $9(9.47)$ \\
\hline \multicolumn{7}{|l|}{ Income in Taka } \\
\hline $\begin{array}{l}\text { lower-income } \\
(<30,000)\end{array}$ & $204(6.3)$ & $14(0.9)$ & $37(5.4)$ & $102(16.9)$ & $41(21.9)$ & $10(10.4)$ \\
\hline $\begin{array}{l}\text { middle-income } \\
(30,000-70,000)\end{array}$ & $1496(46.1)$ & $510(30.9)$ & $433(62.8)$ & $389(64.5)$ & $108(57.8)$ & $56(59.0)$ \\
\hline $\begin{array}{l}\text { High-income } \\
(>70,000)\end{array}$ & $1542(47.7)$ & $\begin{array}{l}1144 \\
(68.59)\end{array}$ & $219(31.8)$ & $112(18.8)$ & $38(20.3)$ & $29(30.5)$ \\
\hline \multicolumn{7}{|l|}{ Occupation } \\
\hline Healthcare workers & $675(20.8)$ & $31(1.9)$ & $212(30.8)$ & $304(50.4)$ & 89 (47.6) & $39(41.1)$ \\
\hline $\begin{array}{l}\text { Non-health care } \\
\text { worker }\end{array}$ & 2567 (79.2) & $1637(98.1)$ & 477 (69.2) & $299(49.6)$ & $98(52.4)$ & $56(59.0)$ \\
\hline
\end{tabular}

\section{Prevalence and $95 \%$ confidence intervals of physical complaints by gender among internet users.}

Table 2 depicts the prevalence and 95\%CIs of the adverse effects on individual physical 
medRxiv preprint doi: https://doi.org/10.1101/2021.08.06.21261689; this version posted August 9, 2021. The copyright holder for this preprint (which was not certified by peer review) is the author/funder, who has granted medRxiv a license to display the preprint in All rights reserved. No reuse allowed without permission.

fingers, respectively. Males reported a higher prevalence of back pain, numbness of the hygiene, and loss of appetite compared with men (Table 2).

Table 2 Gender differences in the prevalence of physical health scores among internet users in Bangladesh. Significant variables between males and females are bolded because the confidence intervals did not overlap.

\begin{tabular}{|c|c|c|c|c|}
\hline \multirow{2}{*}{ Physical complaints } & \multirow[t]{2}{*}{$n$} & \multicolumn{3}{|l|}{ Prevalence $(95 \% \mathrm{CI})$} \\
\hline & & Overall & Male & Female \\
\hline Back pain & 2261 & $69.9[68.27,71.43]$ & $78.14[76.26,79.91]$ & $56.90[54.15,59.62]$ \\
\hline Finger numbness & 2106 & $65.10[63.42,66.71]$ & $72.37[70.35,74.30]$ & $53.65[50.89,56.39]$ \\
\hline Headaches & 2346 & $72.50[70.93,74.01]$ & $78.80[76.94,80.54]$ & $62.62[59.91,65.25]$ \\
\hline Inability to sleep & 1396 & $43.14[41.44,44.85]$ & $41.95[39.79,44.14]$ & $45.00[42.27,47.76]$ \\
\hline Poor Nutrition & 746 & $23.05[21.63,24.54]$ & $16.55[14.97,18.25]$ & $33.25[30.70,35.91]$ \\
\hline Poor Personal Hygiene & 605 & $18.70[17.39,20.08]$ & $14.98[13.47,16.62]$ & $24.52[22.23,26.98]$ \\
\hline Neck pain & 1789 & $55.28[53.56,56.99]$ & $58.50[56.31,60.66]$ & $50.24[47.48,53.00]$ \\
\hline $\begin{array}{l}\text { Dry eyes/other vision } \\
\text { problems }\end{array}$ & 1815 & $56.09[54.37,57.79]$ & $57.54[55.35,59.70]$ & $53.81[51.05,56.55]$ \\
\hline Weight gain/loss & 1653 & $51.08[49.36,52.80]$ & $52.43[50.22,54.63]$ & $48.97[46.21,51.73]$ \\
\hline Loss of Appetite & 499 & $15.42[14.22,16.71]$ & $13.77[12.31,15.36]$ & $18.02[15.99,20.24]$ \\
\hline
\end{tabular}

Figure 1 shows the mean scores of physical health by internet use frequency in males and females. From the figure, the mean scores of physical health by intensive internet use was 5.6 for males and 5.4 for females. This physical health mean scores could be translated as percentage mean scores of males (56\%) and females (54\%), respectively. Physical health mean scores were lower among the casual user of internet ( 3.2 for females and 3.0 for males) than seldom users of internet (3.1 for females and 3.4 for males) 
medRxiv preprint doi: https://doi.org/10.1101/2021.08.06.21261689; this version posted August 9, 2021. The copyright holder for this preprint (which was not certified by peer review) is the author/funder, who has granted medRxiv a license to display the preprint in All rights reserved. No reuse allowed without permission.

Figure 1.

Mean scores by gender of the physical health by internet use frequency in Bangladesh

\section{Unadjusted Analysis for the association between prolonged internet use and physical health complaints}

Table 3 shows the mean scores of physical health complaints and the unadjusted coefficients for the associations with the sociodemographic variables. From the table, the mean scores for physical health complaints varied across variables. The unadjusted coefficients revealed significantly higher physical health problems due to prolonged internet use in those aged >28years, married, completed bachelor education, middle-high income earners and nonhealthcare workers compared with other groups. In contrast, females, those who were divorced or widowed, those with intermediate education, non-workers/students and respondents who resided in Chittagong, Dhaka and Khulna during the study period had significantly lower mean scores of physical health complaints from prolonged internet usage compared with the other groups. 
medRxiv preprint doi: https://doi.org/10.1101/2021.08.06.21261689; this version posted August 9, 2021. The copyright holder for this preprint (which was not certified by peer review) is the author/funder, who has granted medRxiv a license to display the preprint in All rights reserved. No reuse allowed without permission.

\begin{tabular}{|c|c|c|}
\hline Variables & Mean scores (SD) & Unadjusted Coefficient $[95 \% \mathrm{CI}]$ \\
\hline \multicolumn{3}{|l|}{ Gender } \\
\hline Male & $4.85(1.83) * * *$ & Reference \\
\hline Female & $4.47(1.88)$ & $-0.38[-0.51,-0.25]$ \\
\hline \multicolumn{3}{|l|}{ Age, } \\
\hline $18-27$ yrs & $3.52(1.71)^{* * *}$ & Reference \\
\hline $28-37$ yrs & $5.02(1.81)$ & $1.50[1.33,1.67]$ \\
\hline $38+\mathrm{yrs}$ & $4.80(1.77)$ & $1.31[1.12,1.49]$ \\
\hline \multicolumn{3}{|l|}{ Marital status } \\
\hline Single & $3.67(1.76)^{* * *}$ & Reference \\
\hline married & $4.96(1.79)$ & $1.30[1.13,1.47]$ \\
\hline Divorced/widow & $3.00(1.19)$ & $-0.67[-1.04,-0.29]$ \\
\hline \multicolumn{3}{|l|}{ Place of residence } \\
\hline Barisal Division & $5.35(1.83) * * *$ & Reference \\
\hline Chittagong Division & $4.66(1.87)$ & $-0.69[-1.04,-0.35]$ \\
\hline Dhaka Division & $4.36(1.77)$ & $-0.99[-1.28,-0.70]$ \\
\hline Khulna Division & $4.83(1.83)$ & $-0.52[-0.85,-0.19]$ \\
\hline Mymensingh Division & $5.03(1.92)$ & $-0.32[-0.66,0.02]$ \\
\hline Rajshahi Division & $5.21(1.91)$ & $-0.14[-0.51,0.22]$ \\
\hline Rangpur Division & $5.47(1.88)$ & $0.12[-0.26,0.50]$ \\
\hline Sylhet Division & $4.99(1.83)$ & $-0.36[-0.76,0.04]$ \\
\hline \multicolumn{3}{|c|}{ Mother's Level of Education } \\
\hline Higher education & $4.71(1.82)^{* * *}$ & Reference \\
\hline Bachelor & $5.00(1.87)$ & $0.30[0.16,0.43]$ \\
\hline Intermediate (11-12) & $3.65(1.50)$ & $-1.06[-1.26,-0.86]$ \\
\hline \multicolumn{3}{|l|}{ Working status } \\
\hline Employed & $4.89(1.79)^{* * *}$ & Reference \\
\hline Not employed/student & $3.24(1.72)$ & $-1.65[-1.84,-1.46]$ \\
\hline \multicolumn{3}{|l|}{ Income in Taka } \\
\hline lower-income $(<30,000$ & $3.05(1.50)^{* * *}$ & Reference \\
\hline middle-income $(30,000$ & $4.82(1.88)$ & $1.77[1.51,2.04]$ \\
\hline High-income $(>70,000)$ & $4.80(1.77)$ & $1.75[1.48,2.01]$ \\
\hline \multicolumn{3}{|l|}{ Occupation } \\
\hline Healthcare workers & $3.62(1.26)^{* * *}$ & Reference \\
\hline Non-health care workers & $4.98(1.89)$ & $1.36[1.21,1.51]$ \\
\hline
\end{tabular}

The impact of the frequency of internet use on physical health scores

Figure 2 presents the unadjusted and adjusted odds ratio and their confidence intervals for

the association between frequency of internet use and physical health symptoms during the

COVID-19. In the unadjusted analysis, frequent and intensive internet users during the

COVID-19 significantly reported higher physical health problems than seldom users of the internet. After adjusting for the independent variables used in this study, regular, frequent, and intensive internet users during the COVID-19 had significantly higher physical health problems than those who seldom used the internet (see Figure 2). 
medRxiv preprint doi: https://doi.org/10.1101/2021.08.06.21261689; this version posted August 9, 2021. The copyright holder for this preprint (which was not certified by peer review) is the author/funder, who has granted medRxiv a license to display the preprint in All rights reserved. No reuse allowed without permission.

Unadjusted coefficient

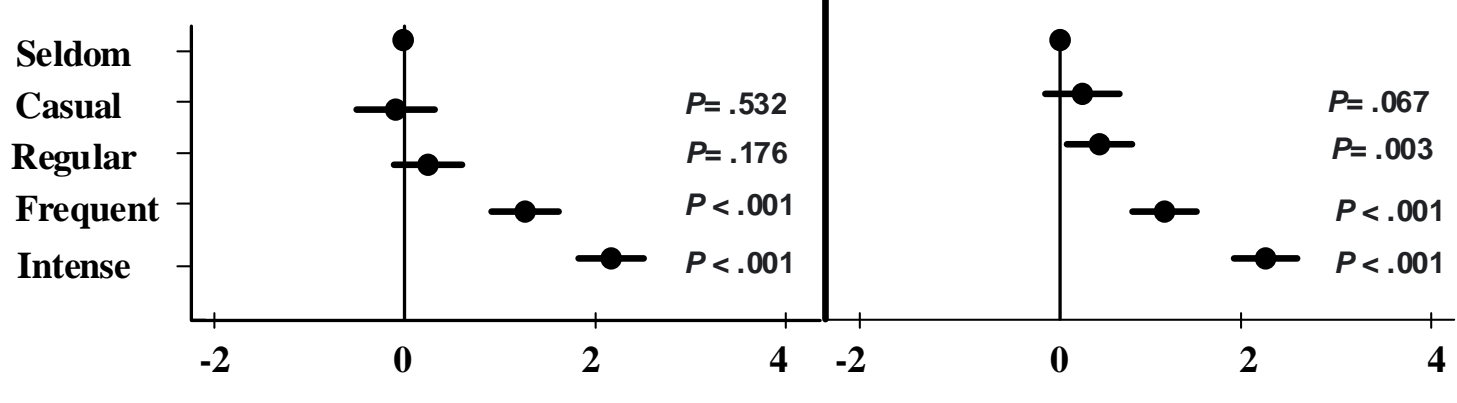

Independent variables adjusted for are Gender, Age group, Division of residence, Mothers Education, marital status, income, working status, occupation.

Figure 2: The impact of frequency of internet use on physical health scores: Unadjusted and adjusted coefficient and their $95 \%$ confidence intervals.

Marital status, age, gender, place of residence, level of education, working status, occupation, and income level were all associated with the physical health complaints among internet users in Bangladesh (Supplementary Table S1 for details).

\section{DISCUSSION}

A considerable body of literature has emerged over the past two decades assessing the relationship between problematic or addictive (excessive) use of the internet and individuals' psychological/mental well-being. Comparatively, very little research has evaluated the relationship between various internet use frequencies and the individual's physical health. The COVID-19 pandemic caused a drastic surge in the use of the internet globally and Bangladesh ${ }^{[1]}$, and this cross-sectional study investigated the relationship between the frequency of internet use and the physical health of Bangladeshi respondents. The findings demonstrated that more than one in every two persons in this study used the internet for seven or more hours each day. This was associated with 2.2 folds increase in physical health problems compared with seldom users ( $<1$ hour per day). Headache, back pain and numbness of the fingers (reported by over seventy percent of internet users) were the predominant complaints. There was a positive association between physical health problems and the number of daily hours spent on the internet. After adjusting for the frequency of internet use, 
medRxiv preprint doi: https://doi.org/10.1101/2021.08.06.21261689; this version posted August 9, 2021. The copyright holder for this preprint (which was not certified by peer review) is the author/funder, who has granted medRxiv a license to display the preprint in All rights reserved. No reusetuity.

292

293

we found that middle to high-income earners and those working in non-healthcare sectors experienced more significant physical health problems due to internet use. In comparison, students and widowed or divorced persons reported fewer physical health problems compared with other respondents.

This study found that headache was the most prevalent symptom reported by internet users in Bangladesh, followed by back pain and numbness of the fingers. These complaints were significantly increased among frequent internet users and intense users, which agrees with the findings of significant association between extensive use of the internet and physical health problems in previous studies ${ }^{[19-22]}$. A study in Spain reported that headache was the most common complaint among internet users during the COVID-19 pandemic ${ }^{[22]}$. Similarly, Cao et al.s study (2009), after examining adolescents, found that those who used the internet excessively were more likely to report psychosomatic symptoms including lack of physical energy, physiological dysfunction, weakened immunity, emotional symptoms, behavioural symptoms and social adaptation problems and had lower life satisfaction scores compared with normal internet users ${ }^{[20]}$.

There are also reports that school children and other graduate students in China ${ }^{[23]}$ and Italy ${ }^{[24]}$ experienced increased psychological distress following excessive internet use during the COVID-19 pandemic. Such addiction to the internet can result in the problem of self-care, difficulty in performing daily routine, and mental health effects of anxiety and depression ${ }^{[25]}$. The negative effects of internet addiction on health may be related to the alterations in the individuals neuroanatomical and neurochemical mechanisms, including cortical thinning of various components of the brain and dopaminergic reward circuitry, during excessive use of the internet ${ }^{[25]}$. While it is imperative that such behaviours, especially during a pandemic, remain at a moderate and regulated level, identifying the population at risk of the problematic use of the internet is necessary in order to prevent the associated mental health problems ${ }^{[26]}$ and improve work or school functions ${ }^{[27]}$. 
medRxiv preprint doi: https://doi.org/10.1101/2021.08.06.21261689; this version posted August 9, 2021. The copyright holder for this preprint (which was not certified by peer review) is the author/funder, who has granted medRxiv a license to display the preprint in All rights reserved. No perpetuity.

The present study further revealed that, compared with women, a higher proportion of men used the internet excessively during the pandemic and thus experienced more significant physical health problems. However, this association was significant only when it interacted with the frequency of internet use. Previous studies among Taiwanese residents ${ }^{[28]}$ and those in mainland China ${ }^{[29]}$ found that male gender was a potential risk factor for internet addiction among adolescents. This association of gender and physical health complaints found in the present study could be explained by the patriarchal nature of the Bangladesh society, where women and girls rarely go outside of their homes even before the pandemic ${ }^{[30]}$ but preferred to stay home and spend more time on the Internet. Whereas these women may have developed adaptive strategies, it was a different experience for the male counterpart, which were used to staying outside/working prior to the lockdown. For these men, the lockdown measures and transition to work online and/or staying at home required them to adjust quickly, try, experiment, and find ways that did not exist before the pandemic ${ }^{[1]}$ as educational institutions, businesses and workplaces were shut down for such a long duration [31]. These adjustments may have affected their physical health.

Another finding of this study was the significant relationship between income class and occupational status (non-healthcare worker) with the physical health problems experienced by internet users. Earning above 30,000 Taka was associated with higher physical health problems due to internet usage after adjusting for the frequency of internet use. In line with this finding, Islam et al ${ }^{[32]}$ on the correlation between problematic (excessive) internet use (PIU) and lifestyle during the COVID-19 pandemic using data from a large sample of Bangladeshi youth and adults $(n=13,525)$ found that younger age, higher education, cigarette smoking, more sleep, less physical activity, gaming and social media use were associated with PIU ${ }^{[32]}$. This research has depicted the physical health concerns related to prolonged internet usage during the COVID-19 pandemic. A similar association was found in this research between educational status, age and physical health complaints among 
medRxiv preprint doi: https://doi.org/10.1101/2021.08.06.21261689; this version posted August 9, 2021. The copyright holder for this preprint (which was not certified by peer review) is the author/funder, who has granted medRxiv a license to display the preprint in All rights reserved. No rerpetuity.

internet users in Bangladesh; however, these associations were dependent on the frequency of internet use, which was not assessed in the previous study ${ }^{[32]}$.

The finding that non-healthcare workers had higher physical health problems compared with health care workers in this study is consistent with the finding of poorer psychological well-being among non-health-care workers who used the Internet to obtain information on COVID-19 compared with those who received COVID-19 information from medical staff in health care settings ${ }^{[33]}$. Although this research were unable to identify whether the non-healthcare workers in our study used the internet for COVID-19 information retrieval, it has been shown that the influx of misinformation around COVID-19 via online platforms had adverse effects on people's health ${ }^{[33]}$. Such problematic internet use (PIU) can lead to clinical impairment, distress ${ }^{[34]}$ and/or deterioration in financial, familial, social, educational and/or occupational domains ${ }^{[35]}$.

This study has some limitations. First, the cross-sectional design of this study does not allow for causality or the direction of relationships to be determined. However, appropriate analysis of cross-sectional data represents a useful initial step in identifying associations between extensive internet usage and the physical health condition of the participants. Second, as the responses were self-reported, it was not possible to verify the participants' physical health complaints, which may lead to a response bias. Multiple assessments, interviews, and informants may have provided a richer and more thorough understanding of this topic. Third, since the survey was administered during COVID-19 lockdown using an online platform, it is possible that some respondents, especially those living in rural areas with limited internet access or people addicted to other online platforms such as gaming or social media, may not have participated in this survey. Although this findings may not represent the opinion of all internet users, a face-to-face survey was not possible at the time due to the lockdown measures. Despite these limitations, this was the first study to investigate the associations between extensive internet use and physical health symptoms in a sample of 
medRxiv preprint doi: https://doi.org/10.1101/2021.08.06.21261689; this version posted August 9, 2021. The copyright holder for this preprint (which was not certified by peer review) is the author/funder, who has granted medRxiv a license to display the preprint in All rights reserved. No reuse allowed without permission.

370

371

372

373

\section{Conclusions}

375

376

377 economies. 
medRxiv preprint doi: https://doi.org/10.1101/2021.08.06.21261689; this version posted August 9, 2021. The copyright holder for this preprint (which was not certified by peer review) is the author/funder, who has granted medRxiv a license to display the preprint in

391

392

393

394

395

396

397

398

399

400

401

402

403

404

405

406

407

408

409

410

411

412

413

414

415

416

417

418

419

420

421

422

423

424

425

426

427

428

429

430

431

432

433

434

\section{References}

1. De' R, Pandey N, Pal A. Impact of digital surge during Covid-19 pandemic: A viewpoint on research and practice. Int J Inf Manage. 2020;55(102171):102171.

2. Garfin DR. Technology as a Coping Tool during the COVID-19 Pandemic: Implications and Recommendations. Stress and Health; 2020.

3. Kawohl W, Nordt C. COVID-19, unemployment, and suicide. Lancet Psychiatry. 2020;7(5):389-390.

4. Király O, Potenza MN, Stein DJ, King DL, Hodgins DC, Saunders JB, Griffiths MD, Gjoneska B, Billieux J, Brand M, Abbott MW, Chamberlain SR, Corazza O, Burkauskas J, Sales CMD, Montag C, Lochner C, Grünblatt E, Wegmann E, Martinotti G, Lee HK, Rumpf H-J, Castro-Calvo J, Rahimi-Movaghar A, Higuchi S, Menchon JM, Zohar J, Pellegrini L, Walitza S, Fineberg NA, Demetrovics Z. Preventing problematic internet use during the COVID-19 pandemic: Consensus guidance. Compr Psychiatry. 2020;100(152180):152180.

5. Ito M, Horst HA, Bittanti M, Herr Stephenson B, Lange PG, Pascoe CJ, Robinson L. Living and learning with new media. In: The MIT Press; 2009:128.

6. O'Keeffe GS, Clarke-Pearson K, Council on Communications and Media. The impact of social media on children, adolescents, and families. Pediatrics. 2011;127(4):800804.

7. Hinduja S, Patchin JW. Offline consequences of online victimization: School violence and delinquency. Journal of school violence. 2007;6(3):89-112.

8. Internet. Gov.bd. Accessed August 6, 2021. http://www.btrc.gov.bd/telco/internet

9. Ayyagari, Grover, Purvis. Technostress: Technological Antecedents and Implications. MIS Q. 2011;35(4):831.

10. Tarafdar M, Tu Q, Ragu-Nathan BS, Ragu-Nathan TS. The impact of technostress on role stress and productivity. J Manag Inf Syst. 2007;24(1):301-328.

11. Kalia A. The Zoom Boom: How Video Calling Became a Blessing-and a Curse. The Guardian; 2020.

12. Osuagwu UL, Miner CA, Bhattarai D, Mashige KP, Oloruntoba R, Abu EK, Ekpenyong B, Chikasirimobi TG, Goson PC, Ovenseri-Ogbomo GO, Langsi R, Charwe DD, Ishaya T, Nwaeze O, Agho KE. Misinformation about COVID-19 in sub-Saharan Africa: Evidence from a cross-sectional survey. Health Secur. 2021;19(1):44-56.

13. Lee JJ, Kang K-A, Wang MP, Zhao SZ, Wong JYH, O’Connor S, Yang SC, Shin S. Associations between COVID-19 misinformation exposure and belief with COVID19 knowledge and preventive behaviors: Cross-sectional online study. J Med Internet Res. 2020;22(11):e22205.

14. Zheng Y, Wei D, Li J, Zhu T, Ning H. Internet use and its impact on individual physical health. IEEE Access. 2016;4:5135-5142.

15. Usgaonkar U, Shet Parkar SR, Shetty A. Impact of the use of digital devices on eyes during the lockdown period of COVID-19 pandemic. Indian J Ophthalmol. 2021;69(7):1901-1906.

16. Lam LT, Peng ZW, Mai JC, Jing J. Faktorer forbundet med internettavhengighet blant ungdom. Cyberpsychol Behav. 2009;12:551-555. 
medRxiv preprint doi: https://doi.org/10.1101/2021.08.06.21261689; this version posted August 9, 2021. The copyright holder for this preprint (which was not certified by peer review) is the author/funder, who has granted medRxiv a license to display the preprint in

17. Heinze G, Dunkler D. Five myths about variable selection. Transpl Int. 2017;30(1):610.

18. Vatcheva KP, Lee M, McCormick JB, Rahbar MH. Multicollinearity in regression analyses conducted in epidemiologic studies. Epidemiology (Sunnyvale). 2016;6(2). doi:10.4172/2161-1165.1000227

19. Morrison CM, Gore H. The relationship between excessive Internet use and depression: a questionnaire-based study of 1,319 young people and adults. Psychopathology. 2010;43(2):121-126.

20. Cao H, Sun Y, Wan Y, Hao J, Tao F. Problematic Internet use in Chinese adolescents and its relation to psychosomatic symptoms and life satisfaction. BMC Public Health. 2011;11:802.

21. Tsai HF, Cheng SH, Yeh TL, Shih CC, Chen KC, Yang YC, Yang YK. The risk factors of Internet addiction - a survey of university freshmen. Psychiatry research. 2009;167(3):294-299.

22. López-Bravo A, García-Azorín D, Belvís R, González-Oria C, Latorre G, SantosLasaosa S, Guerrero-Peral ÁL. Impact of the COVID-19 pandemic on headache management in Spain: an analysis of the current situation and future perspectives. Neurol (Engl Ed). 2020;35(6):372-380.

23. Chen C-Y, Chen I-H, Pakpour AH, Lin C-Y, Griffiths MD. Internet-related behaviors and psychological distress among schoolchildren during the COVID-19 school hiatus. Cyberpsychol Behav Soc Netw. 2021; (cyber.2020.0497). doi:10.1089/cyber.2020.0497

24. Servidio R, Bartolo MG, Palermiti AL, Costabile A. Fear of COVID-19, depression, anxiety, and their association with Internet addiction disorder in a sample of Italian students. Journal of Affective Disorders Reports. 2021;4(100097):100097.

25. Tripathi A. Impact of internet addiction on mental health: An integrative therapy is needed. Integr Med Int. 2018;4(3-4):215-222.

26. Wieckiewicz M, Danel D, Pondel M, Smardz J, Martynowicz H, Wieczorek T, Mazur G, Pudlo R, Wieckiewicz G. Identification of risk groups for mental disorders, headache and oral behaviors in adults during the COVID-19 pandemic. Sci Rep. 2021;11(1):10964.

27. Kelley KJ, Gruber EM. Psychometric properties of the Problematic Internet Use Questionnaire. Comput Human Behav. 2010;26(6):1838-1845.

28. Yen C-F, Ko C-H, Yen J-Y, Chang Y-P, Cheng C-P. Multi-dimensional discriminative factors for Internet addiction among adolescents regarding gender and age: Internet addiction in adolescence. Psychiatry Clin Neurosci. 2009;63(3):357-364.

29. Lam LT, Peng Z-W, Mai J-C, Jing J. Factors associated with Internet addiction among adolescents. Cyberpsychol Behav. 2009;12(5):551-555.

30. Lata LN, Walters P, Roitman S. The politics of gendered space: Social norms and purdah affecting female informal work in Dhaka, Bangladesh. Gend Work Organ. 2021;28(1):318-336.

31. Husain T, Uddin MM, Chowdhury SA, Kalimullah NA. Mental Health Status of Adolescents During the COVID-19 pandemic: A cross-sectional survey among the Bangladeshi graduate students at Dhaka city. bioRxiv. Published online 2020. doi:10.1101/2020.11.12.379487 
medRxiv preprint doi: https://doi.org/10.1101/2021.08.06.21261689; this version posted August 9, 2021. The copyright holder for this preprint (which was not certified by peer review) is the author/funder, who has granted medRxiv a license to display the preprint in All rights reserved. No reuse allowed without permission.

32. Islam MS, Sujan MSH, Tasnim R, Ferdous MZ, Masud JHB, Kundu S, Mosaddek ASM, Choudhuri MSK, Kircaburun K, Griffiths MD. Problematic internet use among young and adult population in Bangladesh: Correlates with lifestyle and online activities during the COVID-19 pandemic. Addict Behav Rep. 2020;12(100311):100311.

33. Ko N-Y, Lu W-H, Chen Y-L, Li D-J, Wang P-W, Hsu S-T, Chen C-C, Lin Y-H, Chang Y-P, Yen C-F. COVID-19-related information sources and psychological wellbeing: An online survey study in Taiwan. Brain Behav Immun. 2020;87:153-154.

34. Shaw M, Black DW. Internet addiction: Definition, assessment, epidemiology and??Clinical management. CNS Drugs. 2008;22(5):353-365.

35. ICD-11 for mortality and morbidity statistics. Who.int. Accessed August 6, 2021. https://icd.who.int/browse11/1-m/en 
medRxiv preprint doi: https://doi.org/10.1101/2021.08.06.21261689; this version posted August 9, 2021. The copyright holder for this preprint (which was not certified by peer review) is the author/funder, who has granted medRxiv a license to display the preprint in All rights reserved. No reuse allowed without permission.

Supplementary Table 1 Results of Multiple Regression Analysis in Prediction of Level of

Physical Complaints Among Internet Users. Bold are significant variables.

\begin{tabular}{lll}
\hline Variables & Adjusted Coefficients [95\% CI] & P-value \\
\hline Gender & Reference & \\
Male & $-0.08[-0.20,0.04]$ & 0.179 \\
Female &
\end{tabular}

\section{Age groups}

$18-27$ yrs

Reference

28-37 yrs

$0.09[-0.13,0.30]$

0.440

$38+$ yrs

$-0.03[-0.29,0.23]$

0.818

\section{Marital status}

Single

married

Divorced/widow

Place of residence

Barisal Division

Chittagong Division

Dhaka Division

Khulna Division

Mymensingh Division

Rajshahi Division

Rangpur Division

Sylhet Division

Mother's Level of Education

Higher education

Bachelor

Intermediate (11-12)

\section{Working status}

Employed

Not employed/student

\section{Income in Taka}

lower-income $(<30,000)$

middle-income $(30,000-70,000)$

High-income $(>70,000)$

\section{Occupation}

Healthcare workers

Non-health care worker

\section{Internet use Frequency}

Seldom

Casual

Regular

Frequent

Intense

Constant

Reference

$$
\text { 0.62 [0.47, 0.78] } \quad<0.0005
$$

Reference

$0.36[-0.02,0.74] \quad 0.067$

$\mathbf{0 . 5 2}[\mathbf{0 . 1 8}, \mathbf{0 . 8 5}] \quad 0.003$

$1.21[0.88,1.54] \quad<0.0005$

2.24 [1.91, 2.57] $<0.0005$

$3.18[2.69,3.67]<0.0005$

